\title{
МОНІТОРИНГ СУЧАСНОГО СТАНУ МІЖРЕГІОНАЛЬНИХ ДИСПРОПОРЦЙ РОЗВИТКУ
}

\section{DOI: 10.32620/cher.2018.4.13}

\begin{abstract}
Постановка проблеми. Для визначення сучасного стану соціально-економічного розвитку регіонів, в статті розглянуто адміністративно-територіальний устрій країни в регіональному розрізі. Метою статmi є аналіз масштабу диспропорцій соціально-економічного розвитку регіонів країни. Об'єктом дослідження є сучасний стан розвитку регіонів України та процес виявлення диспропорцій регіонального розвитку. Гіпотезою дослідження є припущення, що за останні роки у цілому по Україні та в більшості їі регіонів поглиблюється диспропорція розвитку, що характеризується значною демографічною кризою, міжрегіональними розривами у соціально-економічному розвитку. Виклад основного дослідження. Результатом значної диференціації соціально-економічного простору країни є різна спроможність регіонів щодо забезпечення місцевого розвитку: відбувається поглиблення диференціації регіонів за такими показниками як валовий регіональний продукт, доходи населення, середньомісячна заробітна плата, розмах варіації яких по областях на душу населення досягає майже двократного розміру, а рівень безробіття у регіонах з депресивним станом розвитку у 3 раза більше ніж у розвинених. Оригінальність та практичне значення дослідження. Зроблено аналіз питомої ваги регіонів у загальному обсязі по основних макроекономічних показниках - чистий прибуток підприємств, обсяги експорту, імпорту, капітальних інвестицій, роздрібного товарообороту підприємств. Визначено, що розвинені регіони, такі як столичний регіон, Дніпропетровська і Харківська області займають 10,0 - 40,0\% у загальному обсязі, а відсталі регіони Тернопільська, Чернівецька, Кіровоградська області в середньому займають майже 3,0 \% за цими показниками. Ті ж самі тенденції просторового розвитку простежуються і щодо наповненості регіональних бюджетів. Висновки дослідження. Після бюджетного регулювання істотно змінюється рейтинг регіонів за бюджетною забезпеченістю. Якщо Харківська область до надання трансфертів займала шосте місце, то після надання - дев'ятнадцяте, Одеська область з п'ятого місця перемістилась на сімнадцяте, Миколаївська область 3 дев’ятого на вісімнадцяте. I навпаки, такі області, як Сумська, Житомирська і Волинська змінили рейтинг з одинадцятого п’яте, з п'ятнадцятого на десяте, з сімнадцятого на дев'яте відповідно. Така ситуація не дає підстав до розширення власної податкової бази, для створення сприятливих умов розвитку економіки регіону і, тому виникає ефект штучної дотаційності економічно розвинутих регіонів.

Ключові слова:

регіональний розвиток, диспропорція, бюджетне регулювання, товарообмін, імпорт, експорт.
\end{abstract}

\section{MONITORING THE CURRENT STATE OF INTERREGIONAL DEVELOPMENT DISPROPORTION}

Formulation of the problem. In order to determine the current state of socio-economic development of the regions, the administrative-territorial structure of the country is considered in the regional section. The aim of the

${ }^{1}$ Тофанюк Ольга Володимирівна, канд. екон. наук, доцент кафедри «Фінанси», Національний аерокосмічний університет ім. М. Є. Жуковського «Харківський авіаційний інститут», м. Харків, Україна.

Tofaniuk Olga, Ph.D. in Economics, Assistant professor of Finance Department National Aerospace University «Kharkiv Aviation Institute», Kharkiv, Ukraine.

ORCID ID: 0000-0002-2758-6705

e-mail: cooperationkhai@gmail.com

2 Зінчук Альона Сергіївна, канд. екон. наук, аспірант кафедри «Фінанси», Національний аерокосмічний університет ім. М. С. Жуковського «Харківський авіаційний інститут», м. Харків, Україна.

Zinchuk Alona, post-graduate student of Finance Department National Aerospace University «Kharkiv Aviation Institute», Kharkiv, Ukraine.

ORCID ID: 0000-0001-9246-5822

e-mail: alyona1508@ukr.net

${ }^{3}$ Ващенко Олександр Миколайович, канд. екон. наук, доцент кафедри, Харківський національний університет міського господарства імені О. М. Бекетова, м. Харків, Україна.

Vashchenko Oleksandr, Ph.D. in Economics, Assistant professor of Department O. M. Beketov Kharkiv National University of Urban Economy, Kharkiv, Ukraine.

ORCID ID: 0000-0003-3027-7644

e-mail: vashchenko_an@yahoo.com 
research is to analyze the scale of disproportions in the socio-economic development of the country's regions. The object of the research is the current state of development of the regions of Ukraine and the process of identifying regional development disproportions. The hypothesis of the research is the assumption that in recent years in Ukraine and in most of its regions, the developmental imbalance that is characterized by a significant demographic crisis, interregional economic and social disparities deepens. The statement of basic materials. The result of the significant differentiation of the country's socio-economic space is the varying capacity of the regions to ensure local development: there is an intensification of the differentiation of regions according to indicators such as the gross regional product, the income of the population, the average monthly wage, the scope of which varies by regions per capita reaches almost twice the size, and the unemployment rate in regions with a depressed state of development is 3 times more than in developed countries. The originality and practical significance of the research. The analysis of the share of regions in the total volume of the main macroeconomic indicators - net profit of enterprises, volumes of export, import, capital investments, retail turnover of enterprises is made. It has been determined that developed regions such as the metropolitan region, Dnipropetrovsk and Kharkiv regions occupy 10.0-40.0\% of the total, while the backward regions - Ternopil, Chernivtsi, Kirovograd regions occupy almost $3.0 \%$ on these indicators. The same trends of spatial development can be traced to the fullness of regional budgets. Conclusions of the research. After the budget regulation, the ranking of regions for budget security varies significantly. If the Kharkiv region took the sixth place before the transfers, then after granting it - the nineteenth, Odesa region moved from the fifth place to the seventeenth, Nikolayev region from the ninth to the eighteenth. Conversely, such areas as Sumy, Zhytomyr and Volyn changed the rating from the eleventh fifth, from fifteenth to tenth, from the seventeenth to ninth, respectively. This situation does not give grounds for expanding its own tax base, to create favorable conditions for the development of the region's economy and, therefore, there is the effect of artificial subsidization of economically developed regions.

Key words:

regional development, disproportion, budgetary regulation, commodity exchange, import, export.

\section{МОНИТОРИНГ СОВРЕМЕННОГО СОСТОЯНИЯ МЕЖРЕГИОНАЛЬНЫХ ДИСПРОПОРЦИЙ РАЗВИТИЯ}

Постановка проблемы. Постановка проблемы. Для определения современного состояния социально-экономического развития регионов, в статье рассмотрены административно-территориальное устройство страны в региональном разрезе. Целью статьи является анализ масштаба диспропорций социальноэкономического развития регионов страны. Объектом исследования является современное состояние развития регионов Украины и процесс выявления диспропорций регионального развития. Гипотезой исследования является предположение, что за последние годы в целом по Украине и в большинстве ее регионов углубляется диспропорция развития, характеризуется значительной демографическим кризисом, межрегиональными разрывами в социально-экономическом развитии. Изложение основного исследования. Результатом значительной дифференциации социально-экономического пространства страны разная способность регионов по обеспечению местного развития: происходит углубление дифференциации регионов по таким показателям как валовой региональный продукт, доходы населения, среднемесячная заработная плата, размах вариации которых по областям на душу населения достигает почти двукратного размера, а уровень безработицы в регионах с депрессивным состоянием развития в 3 раза больше чем в развитых. Оригинальность и практическое значение исследования. Сделан анализ удельного веса регионов в общем объеме по основным макроэкономическим показателям - чистая прибыль предприятий, объемы экспорта, импорта, капитальных инвестиций, розничного товарооборота предприятий. Определено, что развитые регионы, такие как столичный регион, Днепропетровска и Харьковская области занимают 10,0 - 40,0\% в общем объеме, а отсталые регионы - Тернопольская, Черновицкая, Кировоградская области в среднем занимают почти $3,0 \%$ по этим показателям. Те же тенденции пространственного развития прослеживаются и по наполненности региональных бюджетов. Выводы исследования. После бюджетного регулирования существенно меняется рейтинг регионов по бюджетной обеспеченностью. Если Харьковская область к предоставлению трансфертов занимала шестое место, то после предоставления - девятнадцатый, Одесская область с пятого места переместилась на семнадцатую, Николаевская область с девятого на восемнадцатой. И наоборот, такие области, как Сумская, Житомирская и Волынская изменили рейтинг с одиннадцатого пятых, с пятнадцатого на десятое, с семнадцатого на девятое соответственно. Такая ситуация не дает оснований для расширения собственной налоговой базы, для создания благоприятных условий развития экономики региона и, поэтому возникает эффект искусственной дотационности экономически развитых регионов.

Ключевые слова:

региональное развитие, диспропорция, бюджетное регулирование, товарообмен, импорт, экспорт.

Постановка проблеми. Тенденція збільшення диференціації економічного і соціального розвитку регіонів країни, що просте- жується за останні роки, потенційно загрожує подальшому розшаруванню регіонів за рівнем життя населення, масштабному виникненню 
депресивних територій із застійною економікою, що може уповільнити економічне зростання країни в цілому.

Аналіз останніх досліджень i публікацій. Огляд відповідної літератури показав, що значну увагу приділено дослідженню сучасного стану соцальноекономічного розвитку регіонів та міжрегіональних диспропорцій. Вивченням цих питань займалася значна кількість вчених, однак, необхідно виокремити таких дослідників, як Бабінова О.О. [1], Голиков А.П. [2], Дейнека О.Г. [3], Крайник О.П. [4], Ляшевська O.I. [5], Райнін І.Л. [6] та інші.

Метою статті $\epsilon$ аналіз масштабу диспропорцій соціально-економічного розвитку регіонів країни.

Виклад основного матеріалу дослідження. На погляд О.Г. Дейнеки [3, с. 4], в Україні питання диспропорційності соціально-економічного розвитку $є$ надзвичайно актуальним, що вимагає детального аналізу регіональних особливостей країни.

У своїх дослідженнях І. Л. Райнін [6] та О. О. Бабінова [1] вказують, що основним проблемним питанням сучасного стану місцевого та регіонального розвитку в Україні $\epsilon$ відсутність чіткого розподілу повноважень між різними гілками влади на регіональному та місцевому рівнях, що має бути визначено у національному законодавстві. Найбільш небезпечним серед численних факторів сталого розвитку економіки держави $\epsilon$ регіональні диспропорції. Завдання держави - створити та забезпечити всі умови для повноцінного територіального розвитку.

У монографії О. І. Ляшевської [5], визначено, що на регіональному рівні узагальнюючим показником, який характеризує рівень розвитку економіки регіону, є валовий регіональний продукт. Проведений аналіз міжрегіональних розходжень по виробництву й використанню ВРП на душу населення, що дозволяє зробити висновок про наявність значної диференціації регіонів по обсягах ВРП. Встановлено, що економічне зростання, як головна мета сталого розвитку, має приводити до підвищення стандартів життя, тобто соціальну спрямованість, і супроводжуватися підвищенням реальних показників якості життя населення. На регіональному рівні узагальнюючим показником, який характеризує рівень розвитку економіки регіону, є валовий регіональний продукт.
На думку О. П. Крайник [4], на сучасному етапі розвитку України спостерігається загострення демографічних проблем, що завжди мало місце та зазнало значної актуальності в останні роки.

Відповідно до сучасного адміністративно-територіального устрою Україна підрозділяється на 24 області і місто Київ у якості самостійної адміністративних одиниць. За чисельністю населення, відмічає А.П. Голиков разом 3 іншими дослідниками [2, с. 44-45], Україна займає 6-е місце в Європі (після Росії, Німеччини, Франції, Великобританії, Італії) та має нерівномірний розподіл населення по регіонах.

Розглянемо розташування адміністративно-територіальних одиниць по регіонах країни. На 1 січня 2018 року нараховують 460 міст, 885 селищ міського типу та 28377 сільських населених пункти (табл. 1).

За останні роки у цілому по Україні та в більшості іiі регіонів поглиблюється депресивність їх розвитку. Це обумовлюється тим, що в країні відбувається істотна соціальноекономічна перебудова на основі політичних чинників. Одним 3 наочних показників депресивності просторового розвитку країни виступає значна демографічна криза (табл.2).

У дужках в табл. 2 показана величина приросту населення. Особливо демографічний спад останніх років відбився у таких регіонах як Донецька (скорочення населення від 49,73 тис. чол. у 2014 році до 16,25 тис. чол. у 2018 році) та Луганська області (від 20,79 тис. чол. у 2014 році до 7,29 тис. чол. у 2018 році, до останнього часу в цьому регіоні ситуація найгірша), де продовжується політичний конфлікт, а також у Запорізькій області (від 10,4 тис. чол. у 2010 році до 8,49 тис. чол. у 2018 році), Дніпропетровській області (від 19,0 тис. чол. у 2010 році до 12,23 тис. чол. у 2018 році) і така тенденція є стабільною по всіх регіонах. Постійний приріст населення спостерігається тільки в м. Києві, Київській та Рівненській області, але відносно демографічної кризи всього простору країни, вони мають незначні показники.

Аналізуючи максимальні і мінімальні значення соціально-економічних показників (табл. 3) у регіональному розрізі, також можна визначити суттєві диспропорції у розвитку регіонів. 
Т а б ли ц я 1

Кількість адміністративно-територіальних одиниць в Україні, 2017 рік

\begin{tabular}{|l|c|c|c|c|c|c|}
\hline Регіони України & Райони & Міста & $\begin{array}{c}\text { 3 них міста обла- } \\
\text { сного значення }\end{array}$ & $\begin{array}{c}\text { Райони } \\
\text { в містах }\end{array}$ & $\begin{array}{c}\text { Селища мі- } \\
\text { ського типу }\end{array}$ & $\begin{array}{c}\text { Сільські насе- } \\
\text { лені пункти }\end{array}$ \\
\hline Україна & 490 & 460 & 189 & 111 & 885 & 28377 \\
\hline АР Крим & 14 & 16 & 11 & 3 & 56 & 947 \\
\hline Вінницька & 27 & 18 & 6 & - & 29 & 1457 \\
\hline Волинська & 16 & 11 & 4 & - & 22 & 1054 \\
\hline Дніпропетровська & 22 & 20 & 13 & 18 & 46 & 1435 \\
\hline Донецька & 18 & 52 & 28 & 21 & 131 & 1115 \\
\hline Житомирська & 23 & 12 & 5 & 2 & 43 & 1613 \\
\hline Закарпатська & 13 & 11 & 5 & - & 19 & 578 \\
\hline Запорізька & 20 & 14 & 5 & 7 & 22 & 914 \\
\hline Івано-Франківська & 14 & 15 & 6 & - & 24 & 765 \\
\hline Київська & 25 & 26 & 13 & - & 30 & 1126 \\
\hline Кіровоградська & 21 & 12 & 4 & 2 & 27 & 991 \\
\hline Луганська & 18 & 37 & 14 & 4 & 109 & 780 \\
\hline Львівська & 20 & 44 & 9 & 6 & 34 & 1850 \\
\hline Миколаївська & 19 & 9 & 5 & 4 & 17 & 885 \\
\hline Одеська & 26 & 19 & 9 & 4 & 33 & 1124 \\
\hline Полтавська & 25 & 15 & 6 & 5 & 21 & 1805 \\
\hline Рівненська & 16 & 11 & 4 & - & 16 & 999 \\
\hline Сумська & 18 & 15 & 7 & 2 & 20 & 1455 \\
\hline Тернопільська & 17 & 18 & 4 & - & 17 & 1023 \\
\hline Харківська & 27 & 17 & 7 & 9 & 61 & 1673 \\
\hline Херсонська & 18 & 9 & 4 & 3 & 31 & 658 \\
\hline Хмельницька & 20 & 13 & 6 & - & 24 & 1414 \\
\hline Черкаська & 20 & 16 & 6 & 2 & 15 & 824 \\
\hline Чернівецька & 11 & 11 & 2 & 3 & 8 & 398 \\
\hline Чернігівська & 22 & 16 & 4 & 2 & 29 & 1465 \\
\hline м. Київ & - & 1 & 1 & 10 & - & - \\
\hline м. Севастополь & - & 2 & 1 & 4 & 1 & 29 \\
\hline
\end{tabular}

Джерело: [7]

Т а бли ц я 2

Динаміка демографічної кризи регіонів України

\begin{tabular}{|c|c|c|c|c|c|c|c|c|c|}
\hline \multirow{2}{*}{ Регіони } & \multicolumn{9}{|c|}{ Зменшення кількості населення відносно попереднього року, тис. чол. } \\
\hline & 2010 & 2011 & 2012 & 2013 & 2014 & 2015 & 2016 & 2017 & 2018 \\
\hline Україна & 184,4 & 134,08 & 84,17 & 120,43 & 2510,92 & 168,40 & 176,00 & 198,10 & 122,53 \\
\hline APK & 1,8 & 0,71 & $(1,92)$ & $(2,50)$ & & & & & \\
\hline Вінницька & 9,4 & 6,18 & 6,98 & 8,79 & 8,65 & 8,40 & 11,80 & 14,59 & 7,30 \\
\hline Волинська & $(0,5)$ & $(1,35)$ & $(1,54)$ & $(1,23)$ & $(1,58)$ & 0,20 & 1,70 & 2,54 & 1,49 \\
\hline $\begin{array}{l}\text { Дніпропетров- } \\
\text { ська }\end{array}$ & 19,0 & 15,13 & 12,40 & 15,14 & 17,23 & 21,70 & 24,50 & $(0,74)$ & 12,23 \\
\hline Донецька & 33,7 & 27,23 & 27,69 & 31,35 & 49,73 & 31,90 & 21,10 & 43,54 & 16,25 \\
\hline Житомирська & 6,8 & 5,33 & 4,23 & 6,07 & 7,36 & 8,50 & 7,00 & 9,26 & 5,05 \\
\hline Закарпатська & $(2,6)$ & $(3,12)$ & $(3,88)$ & $(2,51)$ & $(2,69)$ & 0,40 & 0,40 & 0,64 & 1,21 \\
\hline Запорізька & 10,4 & 8,96 & 6,49 & 8,90 & 11,06 & 12,30 & 14,10 & 16,33 & 8,49 \\
\hline $\begin{array}{l}\text { Івано- } \\
\text { Франківська }\end{array}$ & 0,9 & $(0,33)$ & $(1,09)$ & $(1,14)$ & $(0,24)$ & 0,30 & 2,40 & 2,40 & 2,54 \\
\hline Київська & 4,2 & $(1,23)$ & $(3,07)$ & $(3,22)$ & $(4,08)$ & $(3,00)$ & $(2,30)$ & $(19,78)$ & $(4,41)$ \\
\hline Кіровоградська & 7,8 & 6,85 & 7,20 & 7,77 & 7,59 & 7,50 & 7,30 & 9,55 & 4,74 \\
\hline Луганська & 20,3 & 17,22 & 16,40 & 16,90 & 20,79 & 14,60 & 10,10 & 27,50 & 7,29 \\
\hline Львівська & 4,9 & 2,97 & 0,60 & 1,98 & 1,35 & 3,60 & 0,20 & 4,39 & 5,27 \\
\hline Миколаївська & 6,2 & 4,61 & 4,92 & 4,91 & 4,56 & 6,10 & 8,10 & 8,78 & 4,73 \\
\hline
\end{tabular}


Продовження табл. 2

\begin{tabular}{|l|r|r|r|r|r|r|r|r|r|}
\hline \multicolumn{1}{|c|}{1} & \multicolumn{1}{c|}{2} & \multicolumn{1}{c|}{3} & \multicolumn{1}{c|}{5} & \multicolumn{1}{c|}{5} & \multicolumn{1}{c|}{6} & \multicolumn{1}{c|}{7} & \multicolumn{1}{c|}{10} \\
\hline Одеська & 2,3 & 0,73 & $(5,88)$ & $(2,42)$ & $(0,13)$ & 6,10 & 3,80 & 3,43 & 2,67 \\
\hline Полтавська & 11,8 & 9,90 & 9,38 & 9,51 & 10,02 & 10,10 & 12,10 & 12,97 & 6,33 \\
\hline Рівненська & $(0,9)$ & $(1,59)$ & $(2,88)$ & $(1,65)$ & $(2,59)$ & $(0,60)$ & $(0,90)$ & 2,05 & 1,44 \\
\hline Сумська & 10,8 & 8,42 & 8,91 & 10,26 & 10,50 & 10,10 & 8,80 & 10,22 & 5,90 \\
\hline Тернопільська & 4,8 & 3,30 & 3,11 & 3,97 & 3,82 & 4,20 & 6,50 & 6,89 & 3,39 \\
\hline Харківська & 14,0 & 11,98 & $(0,32)$ & 5,61 & 6,54 & 12,70 & 17,40 & 7,19 & 10,47 \\
\hline Херсонська & 5,2 & 4,47 & 4,94 & 5,57 & 5,32 & 5,50 & 6,80 & 8,62 & 4,40 \\
\hline Хмельницька & 7,1 & 6,12 & 5,97 & 7,02 & 6,60 & 6,80 & 9,10 & 10,89 & 4,55 \\
\hline Черкаська & 9,8 & 7,33 & 8,13 & 9,20 & 8,94 & 8,80 & 11,80 & 10,84 & 6,63 \\
\hline Чернівецька & 0,1 & $(0,93)$ & $(1,91)$ & $(1,41)$ & $(1,46)$ & 0,10 & 1,80 & 1,40 & 1,47 \\
\hline Чернігівська & 11,5 & 8,82 & 10,56 & 10,96 & 12,17 & 10,70 & 11,60 & 13,32 & 6,50 \\
\hline м. Київ & $(14,1)$ & $(13,32)$ & $(29,15)$ & $(24,84)$ & $(21,48)$ & $(18,60)$ & $(19,20)$ & $(8,72)$ & $(3,41)$ \\
\hline м. Севастополь & $(0,3)$ & $(0,31)$ & $(2,09)$ & $(2,52)$ & & & & & \\
\hline
\end{tabular}

Джерело: узагальнено авторами на підставі [8]

За розглянутий період відбувається поглиблення диференціації регіонів за показником валового регіонального продукту (розмах варіації цього показника на душу насе- лення досягає більш ніж десятикратного розміру). Близько 70\% регіонів за цим показником на душу населення не досягають середнього рівня по країні.

Т а б ли ц я 3

Співвідношення максимального і мінімального значення показників соціальноекономічного розвитку регіону

\begin{tabular}{|c|c|c|c|c|c|c|}
\hline \multirow{2}{*}{ Показники } & \multicolumn{2}{|c|}{2015} & \multicolumn{2}{|c|}{2016} & \multicolumn{2}{|c|}{2017} \\
\hline & $\max$ & $\min$ & $\max$ & $\min$ & $\max$ & $\min$ \\
\hline \multirow{2}{*}{$\begin{array}{l}\text { Валовий регіональ- } \\
\text { ний продукт на одну } \\
\text { особу, тис. грн. }\end{array}$} & м. Київ & $\begin{array}{l}\text { Луганська } \\
\text { обл. }\end{array}$ & м. Київ & $\begin{array}{l}\text { Луганська } \\
\text { обл. }\end{array}$ & м. Київ & $\begin{array}{c}\text { Луганська } \\
\text { обл. }\end{array}$ \\
\hline & 155,40 & 10,81 & 191,11 & 14,28 & 204,64 & 12,50 \\
\hline $\begin{array}{c}\text { Середньомісячна } \\
\text { заробітна плата, грн. }\end{array}$ & $\begin{array}{l}\text { м. Київ } \\
6706,92\end{array}$ & $\begin{array}{c}\text { Тернопільсь- } \\
\text { ка обл. } \\
3011,00\end{array}$ & $\begin{array}{r}\text { м. Київ } \\
11094,00\end{array}$ & $\begin{array}{c}\text { Тернопіль- } \\
\text { ська обл. } \\
4781,00\end{array}$ & $\begin{array}{c}\text { м. Київ } \\
11454,00\end{array}$ & $\begin{array}{l}\text { Чернівець- } \\
\text { ка обл. } \\
5772,00\end{array}$ \\
\hline $\begin{array}{l}\text { Рівень безробіт- } \\
\text { тя, \% до населення } \\
\text { працездатного віку }\end{array}$ & $\begin{array}{c}\text { Луганська } \\
\text { обл. } \\
16,6\end{array}$ & $\begin{array}{c}\text { Одеська обл. } \\
6,5\end{array}$ & $\begin{array}{c}\text { Луганська } \\
\text { обл. } \\
16,9\end{array}$ & $\begin{array}{c}\text { Харківська } \\
\text { обл. } \\
6,6\end{array}$ & $\begin{array}{c}\text { Луганська } \\
\text { обл. } \\
17,6\end{array}$ & $\begin{array}{c}\text { Харківська } \\
\text { обл. } \\
6,3\end{array}$ \\
\hline $\begin{array}{l}\text { Міграційний рух } \\
\text { населення, тис. осіб }\end{array}$ & $\begin{array}{c}\text { м. Київ } \\
13,46\end{array}$ & $\begin{array}{c}\text { Донецька } \\
\text { обл. } \\
-9,24\end{array}$ & $\begin{array}{c}\text { м. Київ } \\
13,29\end{array}$ & $\begin{array}{c}\text { Донецька } \\
\text { обл. } \\
-3,60\end{array}$ & $\begin{array}{c}\text { Київська } \\
\text { обл. } \\
30,68\end{array}$ & $\begin{array}{l}\text { Донецька } \\
\text { обл. } \\
-23,87\end{array}$ \\
\hline \multirow{2}{*}{$\begin{array}{l}\text { Власні доходи } \\
\text { бюджетів на одну } \\
\text { особу (без трансфе- } \\
\text { ртів), грн. }\end{array}$} & м. Київ & $\begin{array}{l}\text { Закарпатсь- } \\
\text { ка обл. }\end{array}$ & м. Київ & $\begin{array}{l}\text { Луганська } \\
\text { обл. }\end{array}$ & м. Київ & $\begin{array}{c}\text { Луганська } \\
\text { обл. }\end{array}$ \\
\hline & 5132,03 & 1254,45 & 7630,29 & 981,05 & 10003,49 & 1129,28 \\
\hline $\begin{array}{l}\text { Трансферти } \\
\text { на одну особу, грн. }\end{array}$ & $\begin{array}{c}\text { Волинська } \\
\text { обл. } \\
4506,38 \\
\end{array}$ & $\begin{array}{l}\text { Луганська } \\
\text { обл. } \\
1951,98 \\
\end{array}$ & $\begin{array}{c}\text { Волинська } \\
\text { обл. } \\
5501,49\end{array}$ & $\begin{array}{c}\text { Луганська } \\
\text { обл. } \\
1480,00\end{array}$ & $\begin{array}{c}\text { Тернопільсь- } \\
\text { ка обл. } \\
6396,90 \\
\end{array}$ & $\begin{array}{c}\text { Луганська } \\
\text { обл. } \\
1765,00 \\
\end{array}$ \\
\hline
\end{tabular}

Джерело: узагальнено авторами на підставі [13, 14,15]

Низький рівень регіональних податкових надходжень на одного жителя (різниця між регіонами - 2-8 разів), як правило, безпосередньо пов'язаний з вищим, ніж у середньому по країні, рівнем безробіття (різниця між регіонами - 3 рази), низьким обсягом виробленого в регіоні ВРП.
Істотні регіональні відмінності відзначаються і за показником рівня оплати праці. Співвідношення максимального та мінімального рівнів середньої заробітної плати по регіонах за період з 2015 по 2017 роки сягає більше двократного розміру. За наведеними показниками розмах варіації протягом 3-х ро- 
ків зростає, що є свідченням посилення нерівномірності економічного зростання регіонів.

Для визначення й узагальнення рівня розвитку окремих регіонів, детальніше проаналізуємо їх за основними соціальноекономічного показниками в абсолютному i відносному значені. Розглядаючи такий найбільш важливий показник, як валовий регіональний продукт, можна констатувати, що варіація його обсягу у регіонах країни значна - в 12 разів (Дніпропетровська обл. - 252 056,82 млн. грн. і Чернівецька обл. - 21 302,72 млн. грн.), а в розрахунку на душу населення розбіжність у областях складає майже в 3,4 рази (табл.4).

На стан регіонального розвитку істотний вплив має диференціація рівня середньомісячної заробітної плати за регіонами України (табл. 4). Так, у м. Києві середньо- місячна заробітна плата у 2017 році складала 11 454,0 грн., у Донецькій області - 8 133,0 грн., Дніпропетровській - 7 337,0 грн., Київській - 7 459,0 грн., Запорізькій - 7 141,0 грн., тоді як у середньому для України ії рівень склав 6 679,2 грн. У той же час у Тернопільській області середньомісячна оплата праці складала всього 5 798,0 грн., Волинській - 6 025,0 грн., Чернігівській - 5 913,0 грн., Херсонській - 5 969,0 грн., що становило лише $75 \%$ від середнього рівня для економіки України. Таким чином, в Україні присутній істотний розбіг у рівні життя представників різних регіонів (середньомісячна заробітна плата у м. Києві у 2 рази більша, ніж у Чернівецькій області), що ставить додаткові завдання щодо досягнення європейських стандартів життя.

Т а б ли ц я 4

Показники соціально-економічного положення регіонів у 2017 p.

\begin{tabular}{|c|c|c|c|c|c|c|}
\hline \multirow[b]{2}{*}{ Регіони України } & \multicolumn{3}{|c|}{ Валовий регіональний продукт } & \multirow{2}{*}{$\begin{array}{l}\text { Доходи насе- } \\
\text { лення, млн. грн. }\end{array}$} & \multirow{2}{*}{$\begin{array}{c}\text { Рівень заробіт- } \\
\text { ної плати, } \\
\text { грн../чол. }\end{array}$} & \multirow{2}{*}{$\begin{array}{c}\text { Рівень } \\
\text { без- } \\
\text { робіт- } \\
\text { тя, \% }\end{array}$} \\
\hline & мЛн. грн. & $\%$ & $\begin{array}{c}\text { тис. } \\
\text { грн./чол. }\end{array}$ & & & \\
\hline Украӥна & 2445530,85 & 100,0 & 57,70 & 1944250,0 & 6679,2 & 9,9 \\
\hline Вінницька обл. & 75303,93 & 3,08 & 47,79 & 69221,0 & 6433,0 & 11,0 \\
\hline Волинська обл. & 36923,55 & 1,51 & 35,56 & 39580,0 & 6025,0 & 12,6 \\
\hline $\begin{array}{l}\text { Дніпропетровська } \\
\text { обл. }\end{array}$ & 252056,82 & 10,31 & 78,01 & 175159,0 & 7337,0 & 8,8 \\
\hline Донецька обл. & 127187,50 & 5,20 & 30,28 & 105336,0 & 8133,0 & 15,1 \\
\hline Житомирська обл. & 49212,81 & 2,01 & 39,97 & 51644,0 & 6061,0 & 11,3 \\
\hline Закарпатська обл. & 32195,66 & 1,32 & 25,59 & 41885,0 & 6633,0 & 10,8 \\
\hline Запорізька обл. & 109226,18 & 4,47 & 63,39 & 91286,0 & 7141,0 & 11,0 \\
\hline $\begin{array}{l}\text { Івано-Франківська } \\
\text { обл. }\end{array}$ & 54642,45 & 2,23 & 39,67 & 54218,0 & 6289,0 & 9,0 \\
\hline Київська обл. & 135327,18 & 5,53 & 77,14 & 87779,0 & 7459,0 & 6,7 \\
\hline Кіровоградська обл. & 43811,99 & 1,79 & 45,82 & 39283,0 & 6102,0 & 12,6 \\
\hline Луганська обл. & 27091,58 & 1,11 & 12,50 & 35927,0 & 6019,0 & 17,6 \\
\hline Львівська обл. & 116564,63 & 4,77 & 46,08 & 111891,0 & 6617,0 & 7,7 \\
\hline Миколаївська обл. & 57005,59 & 2,33 & 49,95 & 50241,0 & 6842,0 & 10,6 \\
\hline Одеська обл. & 127706,80 & 5,22 & 53,59 & 115600,0 & 6681,0 & 7,4 \\
\hline Полтавська обл. & 111388,58 & 4,55 & 78,79 & 66861,0 & 6966,0 & 12,2 \\
\hline Рівненська обл. & 39666,35 & 1,62 & 34,18 & 45169,0 & 6047,0 & 12,6 \\
\hline Сумська обл. & 47999,62 & 1,96 & 43,86 & 48729,0 & 6159,0 & 9,6 \\
\hline Тернопільська обл. & 32190,59 & 1,32 & 30,59 & 37176,0 & 5798,0 & 12,2 \\
\hline Харківська обл. & 154561,26 & 6,32 & 57,37 & 126220,0 & 6593,0 & 6,3 \\
\hline Херсонська обл. & 38936,72 & 1,59 & 37,19 & 42307,0 & 5969,0 & 11,3 \\
\hline Хмельницька обл. & 53256,31 & 2,18 & 41,79 & 54199,0 & 6166,0 & 9,2 \\
\hline Черкаська обл. & 58223,76 & 2,38 & 47,71 & 49754,0 & 6371,0 & 10,4 \\
\hline Чернівецька обл. & 21302,72 & 0,87 & 23,49 & 32125,0 & 5772,0 & 9,5 \\
\hline Чернігівська обл. & 43231,91 & 1,77 & 42,38 & 42424,0 & 5913,0 & 11,7 \\
\hline м. Київ & 600516,36 & 24,56 & 204,64 & 330236,0 & 11454,0 & 7,4 \\
\hline
\end{tabular}

Джерело: узагальнено авторами на підставі $[9,13,14]$ 
Для аналізу економічного стану регіонів, показник чистого прибутку підприємств $є$ дуже важливим індикатором. Також, для більш повного визначення стану соціальноекономічного розвитку регіонів слід проаналізувати деякі макроекономічні показники, наприклад, такі як об'єми експорту, імпорту, капітальних інвестиції, обсяги роздрібного товарообороту підприємств, що дозволяють зробити аналіз рівня економічної і ділової активності в регіонах.

За даними, які представлені у таблиці 5, видно що у Дніпропетровському регіоні та м. Києві показник чистого прибутку найбільший, а у Донецькому і Луганському найбільші збитки.

Значна перевага експорту над імпортом у Дніпропетровському, Запорізькому і Миколаївському регіонах характеризується специфікою розміщення галузей виробництва промислових підприємств в цих регіонах. Значною перевагою імпорту над експортом характеризується м. Київ, а також Харківський, Київський і Львівський регіони. Перевищення імпорту над експортом у регіонах пояснюється швидким розвитком нових видів послуг та інновацій у виробництві, що вимагає застосування модернізації основних фондів, придбання сучасної продукції машинобудування, транспортних засобів, хімії тощо.

Т а б ли ц я 5

Показники рівня економічної активності регіонів України у 2017 р.

\begin{tabular}{|c|c|c|c|c|c|c|c|c|c|c|}
\hline \multirow{2}{*}{ Регіони України } & \multicolumn{2}{|c|}{$\begin{array}{c}\text { Чистий } \\
\text { прибуток під- } \\
\text { приємств } \\
\end{array}$} & \multicolumn{2}{|c|}{ Експорт } & \multicolumn{2}{|c|}{ Імпорт } & \multicolumn{2}{|c|}{$\begin{array}{c}\text { Обсяг роздрібно- } \\
\text { го товарообороту } \\
\text { підприємств }\end{array}$} & \multicolumn{2}{|c|}{$\begin{array}{l}\text { Капітальні } \\
\text { інвестиції }\end{array}$} \\
\hline & $\begin{array}{l}\text { мЛн. } \\
\text { грн. }\end{array}$ & $\%$ & $\begin{array}{c}\text { млн. } \\
\text { дол. } \\
\text { США } \\
\end{array}$ & $\%$ & $\begin{array}{c}\text { млн. } \\
\text { дол. } \\
\text { США } \\
\end{array}$ & $\%$ & $\begin{array}{l}\text { млн. } \\
\text { грн. }\end{array}$ & $\%$ & $\begin{array}{l}\text { млн. } \\
\text { грн. }\end{array}$ & $\%$ \\
\hline Украӥна & 181692,7 & 100,0 & 43264,74 & 100,0 & 49607,2 & 100,0 & 816553,5 & 100,0 & 448461,5 & 100,0 \\
\hline Вінницька & 9308,2 & 5,12 & 1217,71 & 2,81 & 407,08 & 0,82 & 21097,3 & 2,58 & 11744,1 & 2,62 \\
\hline Волинська & 1651,4 & 0,91 & 689,29 & 1,59 & 1334,97 & 2,69 & 15336,3 & 1,88 & & 1,57 \\
\hline Дніпропетр & 38657,9 & 21,28 & 7052,76 & 16,30 & 4609,55 & 9,29 & 72401,9 & 8,87 & 42908,5 & 9,57 \\
\hline Донецька & $-22846,0$ & $-12,57$ & 4432,60 & 10,25 & 2033,91 & 4,10 & 22482,5 & 2,75 & 172 & 3,85 \\
\hline Житоми & 1588,1 & 0,87 & 589,73 & 1,36 & 449,90 & 0,91 & 20008,5 & 2,45 & 77 & 1,72 \\
\hline Закарпатська & $-586,9$ & $-0,32$ & 1446,42 & 3,34 & 1341,74 & 2,70 & 18316,4 & 2,24 & & 1,25 \\
\hline Запорізька & 16603,2 & 9,14 & 2980,86 & 6,89 & 1328,18 & 2,68 & 36293,3 & 4,44 & 15879,7 & 3,54 \\
\hline Івано-Фран & $-440,2$ & $-0,24$ & 665,40 & 1,54 & 637,20 & 1,28 & 19347,4 & 2,37 & 9707,8 & 2,16 \\
\hline Київська & 10316,3 & 5,68 & 1748 & 4, & 3404 & & 55090,4 & 6,75 & 3449 & 7,69 \\
\hline Кіровогра & 463,6 & 0,26 & 41 & 0,96 & 236 & 0 & 15417,2 & 1,89 & 73 & 1,63 \\
\hline Луга & $-24018,9$ & $-13,22$ & & & & & & 0,71 & & \\
\hline Львін & 2935,4 & 1,62 & 1585,15 & 3,66 & 2180,39 & 0 & 51898,9 & 6,36 & 24 & 5,38 \\
\hline Мик & 3001,0 & 1,65 & 1900,65 & 4,39 & 781,72 & 8 & 522,7 & 2,39 & & 49 \\
\hline Одеська & 4875,6 & 2,68 & 1813,85 & 4,19 & 1427,93 & 2,88 & 62961,7 & 7,71 & 22299,7 & 4,97 \\
\hline Полтавська & 10291,6 & 5,66 & 1864,52 & 4,31 & 1149,72 & 2,32 & 25784,1 & 3,16 & 15855,6 & 3,54 \\
\hline Рівненська & 467,5 & 0,26 & 383,30 & 0,89 & 341,25 & 0,69 & 14933,5 & 1,83 & 6126,8 & 1,37 \\
\hline Сумська & 4610,7 & 2,54 & 672,73 & 1,55 & 551,13 & 1,11 & 16374,2 & 2,01 & 6947,1 & 1,55 \\
\hline Тернопільсь & 1969,8 & 1,08 & 380,19 & 0,88 & & 0,71 & 11679,7 & 1,43 & 7150,6 & 1,59 \\
\hline Харківська & 7674,7 & 4,22 & 1191,54 & 2,75 & 1619,37 & 3,26 & 64891,9 & 7,95 & 19361,7 & 4,32 \\
\hline Херсонська & 3684,6 & 2,03 & 289,15 & 0,67 & 201,43 & 0,41 & 19326,5 & 2,37 & 7362,2 & 1,64 \\
\hline Хмельницька & 6033,7 & 3,32 & 467,64 & 1,08 & 414,26 & 0,84 & 20369,0 & 2,49 & 10499,9 & 2,34 \\
\hline Черкаська & 6373,8 & 3,51 & 617,78 & 1,43 & 403,23 & 0,81 & 19630,9 & 2,40 & 8144,2 & 1,82 \\
\hline Чернівецька & $-380,1$ & $-0,21$ & 149,78 & 0,35 & 113,20 & 0,23 & 13592,7 & 1,66 & 2992,1 & 0,67 \\
\hline Чернігівська & 6025,7 & 3,32 & 625,07 & 1,44 & 445,06 & 0,90 & 15777,4 & 1,93 & 7351,1 & 1,64 \\
\hline м. Київ & 93432,0 & 51,42 & 9738,30 & 22,51 & 19848,6 & 40,0 & 158236,3 & 19,38 & 136044,8 & 30,34 \\
\hline
\end{tabular}

Джерело: узагальнено авторами на підставі $[10,11,12]$

Тісний зв'язок мають показники капітальних інвестицій і обсягу роздрібного товарообороту підприємств. Лідерами стану в цьому визначені є такі регіони - м. Київ, Дніпропетровська, Харківська, Київська і Львівська області, що разом складають майже 50,0\% у за- гальному обсязі. Відсталими за цими показниками є Луганська, Чернівецька, Закарпатська і Рівненська області, що займають менше 5,0 \% загального обсягу.

Розгляд основних макроекономічних показників дає змогу визначення суттєвих 
розбіжностей розвитку територій як в соціальному, економічному так і демографічному сенсі. Результатом зазначених тенденцій $\epsilon$ неоднакова спроможність регіонів щодо забезпечення місцевого розвитку. Тому державна регіональна політика, в контексті подолання депресивності проблемних регіонів, має бути спрямована на вирівнювання регіональних диспропорцій 3 метою створення самодостатніх, високорозвинених в соціально-економічному відношенні регіонів.

Тому вважаємо за потрібне розглянути міжрегіональні відмінності за бюджетними показниками, що мають важливе значення у забезпеченні соціально-економічного розвитку регіонів, і особливо тих, які характеризуються депресивним станом.

Без сумніву, за допомогою комплексного аналізу державних і регіональних фінансових потоків можна розкрити потенційні ре- зерви підвищення ефективності регіональної політики та джерел вирівнювання регіонів, i таким чином сформувати потужні фактори економічного зростання регіонів.

Одним із показників рівня економічної самодостатності регіонів слугують доходи місцевих бюджетів на душу населення до і після бюджетного вирівнювання. В цілому по Україні протягом 2014 - 2016 років вони зросли майже у 2 рази, і за цей період різко посилилась регіональна нерівномірність рівнів місцевих бюджетів. Зокрема, у розглянутий період мінімальний показник 3 трансфертами та без урахування трансфертів мала Луганська область, максимальний показник без трансфертів - Дніпропетровська, 3 трансфертами Полтавська область. Розмах варіації, при цьому, складає до міжбюджетного регулювання $-4,9$ рази, після $-3,6$ рази у 2016 році (табл. 6).

Т а б ли ц я 6

Доходи бюджетів регіонів України у розрахунку на одну особу

Середній рівень доходів бюджетів у розрахунку на одну особу, грн.

\begin{tabular}{|c|c|c|c|c|c|c|c|c|}
\hline \multirow{3}{*}{ Регіони } & \multicolumn{8}{|c|}{ Середній рівень доходів бюджетів у розрахунку на одну особу, грн. } \\
\hline & \multicolumn{4}{|c|}{ без міжбюджетних трансфертів } & \multicolumn{4}{|c|}{ враховуючи міжбюджетні трансферти } \\
\hline & 2014 & 2015 & 2016 & $\begin{array}{l}\text { Рей- } \\
\text { тинг }\end{array}$ & 2014 & 2015 & 2016 & $\begin{array}{l}\text { Рей- } \\
\text { тинг }\end{array}$ \\
\hline Вінницька & 1931,76 & 2365,81 & 3553,45 & 12 & 5309,70 & 7033,27 & 8994,22 & 11 \\
\hline Волинська & 1524,88 & 2118,54 & 2970,51 & 17 & 6031,26 & 7620,02 & 9148,13 & 9 \\
\hline Дніпропетровська & 3366,39 & 4056,47 & 5554,95 & 1 & 5455,81 & 8102,49 & 10051,76 & 3 \\
\hline Донецька & 2246,20 & 1663,08 & 2065,17 & 23 & 4210,40 & 3889,76 & 4239,09 & 23 \\
\hline Житомирська & 1877,79 & 2216,59 & 3242,00 & 15 & 5670,86 & 7157,35 & 9044,34 & 10 \\
\hline Закарпатська & 1254,45 & 1644,77 & 2468,14 & 21 & 5294,46 & 6697,19 & 8041,15 & 22 \\
\hline Запорізька & 2634,58 & 3194,69 & 4988,79 & 3 & 5124,47 & 7243,73 & 9609,31 & 4 \\
\hline Івано-Франківська & 1467,38 & 1860,09 & 2654,25 & 20 & 5466,95 & 7079,00 & 8924,27 & 14 \\
\hline Київська & 2795,28 & 3545,72 & 5317,96 & 2 & 5611,38 & 7857,18 & 10059,38 & 2 \\
\hline Кіровогр & 2082,60 & 2485,87 & 3690,31 & 10 & 5499,80 & 7234,51 & 9122,70 & 8 \\
\hline Луганська & 1489,23 & 981,05 & 1129,28 & 24 & 3441,22 & 2461,05 & 2894,27 & 24 \\
\hline Львівська & 1907,24 & 2531,57 & 3929,12 & 7 & 5181,89 & 7282,02 & 9213,73 & 7 \\
\hline Миколаївська & 2074,55 & 2541,01 & 3772,63 & 9 & 5256,89 & 6978,67 & 8636,12 & 18 \\
\hline Одеська & 2339,97 & 2903,61 & 4510,08 & 5 & 5196,17 & 6906,08 & 8707,31 & 17 \\
\hline Полтавська & 2699,38 & 3351,80 & 4858,00 & 4 & 5303,86 & 7698,52 & 10302,50 & 1 \\
\hline Рівненська & 1615,91 & 1900,84 & 2685,56 & 19 & 5922,84 & 7383,28 & 8978,67 & 12 \\
\hline Сумська & 2038,54 & 2441,84 & 3620,55 & 11 & 5163,43 & 7063,42 & 9391,04 & 5 \\
\hline Тернопільсы & 1311,71 & 1746,18 & 2427,87 & 22 & 5198,80 & 6781,74 & 8824,77 & 16 \\
\hline Харківська & 2404,72 & 2895,76 & 4185,40 & 6 & 5171,09 & 6787,43 & 8482,82 & 19 \\
\hline Херсонська & 1711,21 & 2139,59 & 3125,99 & 16 & 5246,47 & 6606,46 & 8112,92 & 21 \\
\hline Хмельницька & 1794,42 & 2266,46 & 3244,22 & 14 & 5474,10 & 7144,70 & 8969,11 & 13 \\
\hline Черкаська & 2062,79 & 2569,11 & 3777,29 & 8 & 5402,22 & 7159,29 & 9338,78 & 6 \\
\hline Чернівецька & 1367,91 & 1819,98 & 2785,93 & 18 & 5238,68 & 6702,82 & 8397,31 & 20 \\
\hline Чернігівська & 1886,90 & 2328,80 & 3533,29 & 13 & 5340,06 & 6884,69 & 8839,07 & 15 \\
\hline Max & 3366,39 & 4056,47 & 5554,95 & & 6031,26 & 8102,49 & 10302,50 & \\
\hline Min & 1254,45 & 981,05 & 1129,28 & & 3441,22 & 2461,05 & 2894,27 & \\
\hline Max/Min & 2,7 & 4,1 & 4,9 & & 1,8 & 3,3 & 3,6 & \\
\hline
\end{tabular}

Джерело: узагальнено авторами на підставі [15] 
Отже, фінансова підтримка регіонів може здійснюватися шляхом закріплення за місцевими бюджетами державних доходів, проте ці кошти, як правило, є недостатніми для адекватного фінансування їхньої діяльності і викликає зростання диференціації фінансової забезпеченості регіональних і місцевих бюджетів. Тому важливу роль у бюджетному регулюванні соціально-економічного розвитку регіонів мають міжбюджетні трансферти

До того ж, після бюджетного регулювання істотно змінився рейтинг регіонів за цим показником. Наприклад, Харківська область до надання трансфертів займала 6-е місце, після надання аж 19-е, Одеська область 3 5-го місця перемістилась на 17-е, Миколаївська область 3 9-го на 18-е. I навпаки, такі області, як Сумська, Житомирська і Волинська змінили рейтинг 3 11-го на 5-е, $з$ 15-го на 10-е, з 17-го на 9-е відповідно.

В табл. 7 порівняно динаміку і темп росту міжбюджетних трансфертів і валового регіонального продукту у регіональному розрізі. На протязі 2014 - 2016 рр. темп росту трансфертів та валового регіонального продукту майже в усіх регіонах зменшився. Таке становище говорить про недофінансування бюджетної сфери регіонів та загальне зменшення їх ділового тонусу.

Т а б ли ц я 7

\section{Динаміка ВРП і міжбюджетних трансфертів по регіонах}

\begin{tabular}{|c|c|c|c|c|c|c|c|c|c|c|c|c|}
\hline \multirow[t]{2}{*}{ Регіони } & \multicolumn{3}{|c|}{$\begin{array}{c}\text { Міжбюджетні тран- } \\
\text { сферти у розрахунку на } \\
\text { одну особу, грн. }\end{array}$} & \multicolumn{3}{|c|}{$\begin{array}{c}\text { Валовий регіональний } \\
\text { продукт у розрахунку } \\
\text { на одну особу, грн. }\end{array}$} & \multicolumn{3}{|c|}{$\begin{array}{l}\text { Темп росту міжбюд- } \\
\text { жетних трансфертів } \\
\text { (до попер. року), \% }\end{array}$} & \multicolumn{3}{|c|}{$\begin{array}{c}\text { Темп росту валовогс } \\
\text { регіонального } \\
\text { продукту } \\
\text { (до попер. року), \% }\end{array}$} \\
\hline & 2014 & 2015 & 2016 & 2014 & 2015 & 2016 & 2015 & 2016 & $\begin{array}{l}\text { нап- } \\
\text { рям } \\
\text { зміни }\end{array}$ & 2015 & 2016 & $\begin{array}{c}\text { нап- } \\
\text { рям } \\
\text { зміни }\end{array}$ \\
\hline Вінницька & 3377,93 & 4667,46 & 5440,77 & 27312,8 & 37368,0 & 46787,6 & 138 & 116,6 & $\downarrow$ & 136,8 & 125,2 & $\downarrow$ \\
\hline Волинська & 4506,38 & 5501,49 & 6177,62 & 23199,7 & 30390,3 & 34336,2 & 122,1 & 112,3 & $\uparrow$ & 131,0 & 113,0 & $\downarrow$ \\
\hline Дніпропетр & 2089,42 & 4046,02 & 4496,81 & 53879,0 & 66117,5 & 75680,4 & 193,6 & 111,1 & $\downarrow$ & 122,7 & 114,5 & $\uparrow$ \\
\hline Донецька & 1964,21 & 2226,68 & 2173,92 & 27922,5 & 26965,8 & 32398,7 & & 97,6 & $\downarrow$ & 96,6 & 120,1 & $\uparrow$ \\
\hline Житомирська & 3793,07 & 4940,76 & 5802,34 & 23738,1 & 30801,6 & 38628,8 & & 117,4 & $\downarrow$ & 129,8 & 125,4 & $\downarrow$ \\
\hline Закарпатська & 4040,01 & 5052,41 & 5573,01 & 19148,9 & 22992,4 & 25730,9 & 125,1 & & $\downarrow$ & 120,1 & 111,9 & $\downarrow$ \\
\hline Запорізька & 2489,89 & 4049,04 & 4620,52 & 37356,6 & 50787,5 & 59973,0 & 162,6 & 11 & $\downarrow$ & 136,0 & 118,1 & $\downarrow$ \\
\hline Івано-Фран & 3999,57 & 5218,91 & 6270,02 & 27226,2 & & 37252,0 & & & $\downarrow$ & & 112,3 & $\downarrow$ \\
\hline Київська & 2816,10 & 4311,45 & 4741,42 & 46010,3 & 60056,6 & 74164,3 & 15 & 110,0 & $\downarrow$ & 130,5 & 123,5 & $\downarrow$ \\
\hline Кіровогра & & & & 29326,9 & & & & & $\downarrow$ & & 120,6 & $\downarrow$ \\
\hline Луганська & 1951,98 & 1480,00 & 1765,00 & 14141,0 & 10813,9 & 14283,2 & & & $\uparrow$ & 76,5 & 132,1 & $\uparrow$ \\
\hline Львів & & 4750,45 & 5284,61 & 28734,7 & 37364,8 & 45320,4 & 1 & & $\downarrow$ &, 0 & 1,3 & $\downarrow$ \\
\hline Миколаївська & 3182,34 & 4437,66 & 4863,49 & 30411,4 & 41612,0 & 50269,5 & & 109 & $\downarrow$ & 136,8 & 120,8 & $\downarrow$ \\
\hline Оде & & & 4197,23 & 31269,4 & 417 & 50199,0 & 140,1 & 104,9 & $\downarrow$ & 133,5 & 120,3 & $\downarrow$ \\
\hline Полтавська & 2604,49 & 4346,72 & \begin{tabular}{|l|}
5444,49 \\
\end{tabular} & 48192,5 & 66625,2 & 81491,4 & & 12 & $\downarrow$ & 138,2 & 122,3 & $\downarrow$ \\
\hline Рівненська & 4306,92 & 5482,44 & 6293,11 & 24736,5 & 30342,6 & 33946,0 & 127,3 & 114,8 & $\downarrow$ & 122,7 & 111,9 & $\downarrow$ \\
\hline Сумська & 3124,89 & 4621,58 & 5770,48 & 27058,0 & 37336,7 & 41907,7 & & & $\downarrow$ & 138,0 & 112,2 & $\downarrow$ \\
\hline Тернопільська & 3887,09 & 5035,56 & 6396,90 & 20259,8 & 25012,7 & 29335,3 & 129,5 & 127,0 & $\downarrow$ & 123,5 & 117,3 & $\downarrow$ \\
\hline Харківська & 2766,37 & 3891,67 & 4297,42 & 35366,3 & 45921,8 & 57334,1 & 140,7 & 110,4 & $\downarrow$ & 129,8 & 124,9 & $\downarrow$ \\
\hline Херсонська & 3535,26 & 4466,87 & \begin{tabular}{|l|}
4986,93 \\
\end{tabular} & 21771,7 & 30322,9 & 36702,3 & 126,4 & 111,6 & $\downarrow$ & 139,3 & 121,0 & $\downarrow$ \\
\hline Хмельницька & 3679,68 & 4878,24 & 5724,89 & 24717,2 & 31742,9 & 38013,7 & 132,6 & 117,4 & $\downarrow$ & 128,4 & 119,8 & $\downarrow$ \\
\hline Черкаська & 3339,43 & 4590,19 & 5561,48 & 30728,6 & 40903,5 & 48255,4 & 137,5 & 121,2 & $\downarrow$ & 133,1 & 118,0 & $\downarrow$ \\
\hline Чернівецька & 3870,77 & 4882,84 & 5611,39 & 16537,4 & 20338,5 & 23388,4 & 126,1 & 114,9 & $\downarrow$ & 123,0 & 115,0 & $\downarrow$ \\
\hline Чернігівська & 3453,16 & 4555,89 & 5305,79 & 26670,5 & 35374,2 & 41960,5 & 131,9 & 116,5 & $\downarrow$ & 132,6 & 118,6 & $\downarrow$ \\
\hline м. Київ & 3377,93 & 4667,46 & 5440,77 & 27312,8 & 37368,0 & 46787,6 & 138,2 & 116,6 & $\downarrow$ & 136,8 & 125,2 & $\downarrow$ \\
\hline
\end{tabular}
Джерело: узагальнено авторами на підставі $[9,15]$

Відсутність взаємозв'язку між обсягом зібраних податків в регіоні і його видатками означає, що у місцевих органів влади немає стимулів для розширення власної податкової бази i, відповідно, для створення сприятливих умов для розвитку економіки регіону, особливо це стосується економічно слабших регіонів.
На нашу думку, рейтинги регіонів у забезпеченості їхніх бюджетів до і після міжбюджетного регулювання мають змінюватись несуттєво. Допомога регіонам має залежати від власних зусиль регіональної влади підвищити стан соціально-економічного розвитку свого регіону. 
Тому, питання регіональної політики в Україні стають все більш актуальними.

Таким чином, забезпечення необхідного обсягу місцевого бюджету відбувається значною мірою через надання допомоги регіонам. На нашу думку, бюджетне регулювання має зменшувати нерівність соціальноекономічного розвитку регіонів, але ранжування регіонів при цьому має зберігатись. До того ж, виникає ефект штучної дотаційності деяких регіонів, адже 9 регіонів (Дніпропетровська, Донецька, Запорізька, Київська, Одеська, Харківська, Львівська, Полтавська області, м. Київ) мають вищій за середній по Україні показник доходів місцевих бюджетів на одну особу до бюджетного регулювання i при цьому є дотаційними.

Висновки та перспективи подалыших досліджень. Проведені розрахунки дозволяють стверджувати, що сучасний етап розвитку економічного простору України характеризується високим рівнем процесів диференціації. Вважаємо, для того, щоб підвищити ефективність національної і регіональної економічної політики, концепцій і стратегій розвитку окремих регіонів і територіальноадміністративних одиниць, необхідно, насамперед, визначити регіони, які потребують пріоритетної державної підтримки, і при цьому аналізувати не тільки рівень їх дотаційності або надходження інших трансфертів. Для цього необхідно визначити проблемні регіони на основі рейтингової оцінки соціальноекономічного положення регіонів, враховуючи цілу низку показників. Зменшення значних диспропорцій регіонального розвитку надасть змогу налагодження соціально-економічної ситуації у економічно розвинутих регіонах та нарешті досягнення самостійності місцевих та регіональних бюджетів.

\section{Література}

1. Бабінова О. О. Державна регіональна політика і регіональний розвиток: сучасні реалії України та європейський досвід / О. О. Бабінова. - Київ: Фенікс, 2011. - 268 с.

2. Голиков А. П. Економіка України: фактори виробництва, галузева структура, розміщення, тенденції розвитку: [навчальний посібник для студентів вищих навчальних закладів] / А.П. Голиков, Н.А. Казакова, О.А. Шуба. - [2-ге вид.]. - Х.: ХНУ імені В.Н. Каразіна, 2005. - 240 с.
3. Дейнека О. Г. Регіональний аспект диспропорцій соціально-економічного розвитку України / О. Г. Дейнека // Економіка та управління підприємствами машинобудівельної галузі: проблеми теорії та практики. - X.: XAI. - 2009. - №1 (5). - C. 4-13.

4. Крайник О. П. Соціальноекономічний розвиток регіону: механізми державного впливу: монографія / О. П. Крайник, Г. С. Третяк, О. М. Чемерис, I.I. Козак. - Львів: ЛРІДУ НАДУ, 2011. - 232 с.

5. Лямевська О. I. Державне регулювання валового регіонального продукту як чинник сталого розвитку регіону: монографія / O. I. Ляшевська. - Харків: «Друкарня Мадрид», 2016. - $200 \mathrm{c}$.

6. Райнін І. Л. Адміністративно-правове регулювання управління розвит-ком регіону: монографія / І. Л. Райнін. - Харків: Золота миля, 2016. $-616 \mathrm{c}$.

7. Статистична інформація. Демографічна ситуація. Кількість адміністративно-територіальних одиниць в Україні / Офіційний сайт Державного комітету статистики України. [Електронний ресурс]. Режим доступу до сайту: http://www.ukrstat.gov.ua/
8. Статистична
інформація. Демографічна ситуація. Чисельність населення (щомісячна інформація). Чисельність населення за 2017 p. / Офіційний сайт Державного комітету статистики України. [Електронний pecypc]. - Режим доступу до сайту: http://www.ukrstat.gov.ua/

9. Статистична

інформація. Національні рахунки. Валовий регіональний продукт (2017рр.) / Офіційний сайт Державного комітету статистики України. [Електронний pecypc]. - Режим доступу до сайту: http://www.ukrstat.gov.ua/

10. Статистична інформація. Соціальноекономічне становище регіонів України. Обсяг експорту-імпорту товарів і послуг за регіонами України за 2017 рік / Офіційний сайт Державного комітету статистики України. [Електронний ресурс]. - Режим доступу до сайту: http://www.ukrstat.gov.ua/

11. Статистична інформація. Соціальноекономічне становище регіонів України. Інвестиційна та будівельна діяльність (щомісячна інформація). Капітальні інвестиції за 2017 рік / Офіційний сайт Державного комітету статистики України. [Електронний pecypc]. - Режим доступу до сайту: http://www.ukrstat.gov.ua/

12. Статистична інформація. Соціальноекономічне становище регіонів України. Спо- 
живчий ринок (щомісячна інформація). Обсяг роздрібного товарообороту підприємств за січень-грудень 2017 року / Офіційний сайт Державного комітету статистики України. [Електронний ресурс]. - Режим доступу до сайту: http://www.ukrstat.gov.ua/

13. Статистична інформація. Соціальноекономічне становище регіонів України. Заробітна плата та стан іiі виплати (щомісячна інформація) Середньомісячна заробітна плата за регіонами за період 3 початку 2017 року / Офіційний сайт Державного комітету статистики України. [Електронний ресурс]. - Режим доступу до сайту: http://www.ukrstat.gov.ua/

14. Статистична інформація. Соціальноекономічне становище регіонів України. Ринок праці. Зареєстроване безробіття населення за регіонами у 2017 році / Офіційний сайт Державного комітету статистики України. [Електронний ресурс]. - Режим доступу до сайту: http://www.ukrstat.gov.ua/

15. Статистичний збірник «Бюджет 2016» / Офіційний сайт Міністерства фінансів України. [Електронний ресурс] - Режим доступу до сайту: http://www.minfin.gov.ua/

\section{References}

1. Babinova, O. O. (2011). State regional policy and regional development: modern realities of Ukraine and European experience. Kyiv: Phoenix, 268.

2. Golikov, A. P. \& Kazakova, N.A. \& Shuba $O$. A. (2005). Economy of Ukraine: factors of production, branch structure, location, development trends: [textbook for students of higher educational institutions]. Kharkiv: KhNU named V.N. Karazin. 240.

3. Deineka, O. G. (2009). Regional aspect of the disproportions of socio-economic development of Ukraine. Economics and management of enterprises of the machine-building industry: problems of theory and practice. Kharkiv. KhAI, 1(5), 4-13.

4. Krynik, O. P. \& Tretiak, G. S. \& Chemeris, A. M. \&. Cossack, I. I. (2011). Socio-economic development of the region: mechanisms of state influence: monograph. Lviv: LRIT NAPA, 232.

5. Lyashevskaya, O. I. (2016). State regulation of gross regional product as a factor of sustainable development of the region: monograph. Kharkiv: "Typography Madrid", 200.

6. Rainin, I. L. (2016). Administrative and legal regulation of management of the develop-

Стаття надійшла

до редакції : 02.09.2018 p. ment of the region: monograph. Kharkiv: Golden mile, 616 .

7. Statistical information. Demographic situation. Number of administrative-territorial units in Ukraine / Official site of the State Statistics Committee of Ukraine. Retrieved from: http://www.ukrstat.gov.ua/

8. Statistical information. Demographic situation. Population (monthly information). Population in 2017 / Official site of the State Statistics Committee of Ukraine. Retrieved from: http://www.ukrstat.gov.ua/

9. Statistical information. National Accounts. Gross regional product (2017 gg.) / Official site of the State Statistics Committee of Ukraine. Retrieved from: http://www.ukrstat.gov.ua/

10. Statistical information. Socio-economic situation of the regions of Ukraine. Volume of export-import of goods and services by regions of Ukraine for 2017 / Official site of the State Statistics Committee of Ukraine. Retrieved from: http://www.ukrstat.gov.ua/

11. Statistical information. Socio-economic situation of the regions of Ukraine. Investment and construction activities (monthly information). Capital investment for 2017 / Official site of the State Statistics Committee of Ukraine. Retrieved from: http://www.ukrstat.gov.ua/

12. Statistical information. Socio-economic situation of the regions of Ukraine. Consumer market (monthly information). Volume of retail turnover of enterprises for January-December 2017 / Official site of the State Committee of Statistics of Ukraine. Retrieved from: http://www.ukrstat.gov.ua/

13. Statistical information. Socio-economic situation of the regions of Ukraine. Salary and the state of its payment (monthly information) Average monthly wages by region for the period from the beginning of 2017 / Official site of the State Statistics Committee of Ukraine. Retrieved from: http://www.ukrstat.gov.ua/

14. Statistical information. Socio-economic situation of the regions of Ukraine. Labor market. Registered Unemployment by Region in 2017 / Official Site of the State Statistics Committee of Ukraine. Retrieved from: http://www.ukrstat.gov.ua/

15. Statistical collection "Budget 2016" / Official site of the Ministry of Finance of Ukraine. Retrieved from: http://www.minfin.gov.ua/

Стаття прийнята до друку:

20.11.2018 p. 